DOI: $10.19195 / 0524-4544.327 .26$

\author{
MAGDALENA TABERNACKA \\ ORCID: 0000-0002-5921-7154 \\ Uniwersytet Wrocławski \\ magdalena.tabernacka@uwr.edu.pl
}

\title{
Syndrom wypalenia zawodowego w administracji publicznej
}

\begin{abstract}
Abstrakt: Wypalenie zawodowe jest stanem odczuwanym przez pracownika w sferze jego psychiki, somatyki i funkcjonowania społecznego. Zjawisko to ma ogromy wpływ na funkcjonowanie struktury, w której jest zatrudniona dana osoba. W przypadku zatrudnienia w instytucjach administracji publicznej wystąpienie tego syndromu warunkowane jest zarówno swoistymi czynnikami związanymi z organizacją i kulturą pracy w danej strukturze administracji publicznej, jak i założeniami ustrojowymi i organizacyjnymi funkcjonowania danej struktury. Syndrom wypalenia zawodowego u pracowników i urzędników administracji publicznej występuje z podobną częstotliwością jak u całej pracującej populacji, jednak w przypadku osób zatrudnionych w strukturach niosących pomoc jego ryzyko jest wyraźnie większe. Wśród remediów na to zjawisko istotną rolę odgrywa superwizja oraz szczególny klimat organizacyjny oferujący wsparcie i poszanowanie innych niż zawodowe sfer funkcjonowania społecznego pracownika bądź urzędnika administracji publicznej.
\end{abstract}

Słowa kluczowe: wypalenie zawodowe, administracja publiczna, pracownicy i urzędnicy administracji publicznej, struktury administracji publicznej, stosunki pracownicze w administracji publicznej.

\section{Zakres badań nad zjawiskiem wypalenia zawodowego w administracji publicznej}

Studia nad szczególnymi zjawiskami zachodzącymi w obrębie administracji publicznej powinny przebiegać z perspektywy uwzględniającej holistyczne ujęcie jej trzech postaci, o których pisał profesor Jan Boć, czyli struktur, działań i ludzi. Oczywiście każda z tych postaci, jak również każdy z fenomenów występujących w ich obrębie, może być poddawana selektywnym analizom. Niemniej jedynie 
kompleksowe ujęcie określonego zjawiska występującego w administracji, obejmujące jego kluczowe aspekty uwzględniające perspektywy tych trzech płaszczyzn, pozwoli na prawidłowe zidentyfikowanie zjawiska, opisanie go i znalezienie odpowiedzi na szereg istotnych pytań, które były bodźcem do podjęcia studiów nad danym przypadkiem. Jak to ujmował profesor Jan Boć, administrację trzeba by wyodrębniać, pokazywać i badać tak, jak się ona kształtowała czy kształtuje1. A to wymaga szerszego spojrzenia.

Wypalenie zawodowe jest syndromem, w którym ogniskują się uwarunkowania strukturalne i funkcjonalne administracji oraz podmiotowe czy też — jeżeli by ująć to w sposób, który kilkadziesiąt lat temu był popularny - uwarunkowania związane z „czynnikiem ludzkim”. Ponieważ wypalenie zawodowe w administracji publicznej dotyczy ludzi w niej zatrudnionych i działających na rzecz wykonywania zadań publicznych, kondycja tych osób siłą rzeczy musi oddziaływać zarówno na sposób wykonania owych zadań, jak i w znaczący sposób determinować funkcjonowanie struktur administracji, a czasem wręcz ich organizację. Jest to więc zjawisko, które będąc bezpośrednio związane z tym ujęciem administracji, które J. Boć przedstawiał jako „ludzi zatrudnionych (powołanych, nominowanych, wybieranych, przyjętych do pracy w oparciu o umowę cywilną) w strukturach" administracji, która ma na zasadzie sprzężenia zwrotnego wpływ właśnie na te „wydzielone w państwie struktury organizacyjne powołane specjalnie do realizacji określonych celów o charakterze zadań publicznych"” oraz także na podejmowanie działań w tych strukturach, co J. Boć opisywał jako „określoną i o specjalnych cechach działalność podejmowaną w ramach realizacji celów o charakterze publicznym"4. Skorelowane badania nad wypaleniem zawodowym uwzględniające perspektywę poszczególnych postaci administracji publicznej w swoistym dla nich dynamicznym ujęciu pozwalają więc wyjaśnić zjawisko wypalenia zawodowego dotyczącego ludzi zatrudnionych w strukturach administracji publicznej. W niniejszym opracowaniu przedstawione zostaną istotne aspekty wpływu na ludzi zatrudnionych w administracji publicznej uwarunkowań strukturalnych i środowiskowych w kontekście ryzyka wystąpienia u nich syndromu wypalenia zawodowego.

Wpływ na funkcjonowanie ludzi wykonujących zadania publiczne w strukturach administracji publicznej powinny mieć w pierwszym rzędzie uwarunkowania prakseologiczne, jednak nie tylko one oddziałują na warunki pracy osób sprawujących funkcje w administracji publicznej. Istnieją też inne uwarunkowania, których wpływ jest kluczowy. U źródeł regulacji prawnych określających kształtowanie struktur administracji i procedury działania jej organów leżą swoiste uwarun-

1 J. Boć, Konteksty wyróżnienia administracji publicznej, [w:] Administracja publiczna, red. J. Boć, Wrocław 2013, s. 17.

2 J. Boć, Pojęcie administracji, [w:] Prawo administracyjne, red. J. Boć, Wrocław 2010, s. 12.

3 Ibidem.

${ }^{4}$ Ibidem. 
kowania aksjologiczne wyznaczane przyjętymi w danym państwie założeniami ustrojowymi. Ponadto da się zauważyć pewne czynniki determinujące zachowanie osób funkcjonujących w administracji publicznej, które może w idealnym jej modelu nie powinny mieć na nią decydującego wpływu, ale realnie wpływ ten jest istotny. Przede wszystkim chodzi o znaczenie, jakie dla regulacji determinujących funkcjonowanie oraz sposób działania administracji publicznej mają koncepcje polityczne, a często także swoiste doraźne polityczne racje. Odczuwalne jest oddziaływanie tych czynników nawet na sprawę tak pragmatyczną, jak warunki pracy w określonych urzędach czy też jednostkach organizacyjnych wyodrębnionych w ramach administracji publicznej. Jak zauważył A. Błaś, ustrój administracji publicznej nie wyraża prakseologicznie pojmowanego podziału pracy w organizacji lecz jest wyrazem koncepcji ustrojowo-prawnej. ${ }^{5}$. Warunki i komfort pracy (lub jego brak) pracownika czy funkcjonariusza administracji jest więc warunkowany także czynnikami z pozoru tak odległymi od jego codzienności zawodowej, jak założenia ustrojowe będące podstawą kształtowania struktury, w której jest zatrudniony.

\section{Wypalenie zawodowe w strukturach administracji publicznej}

Zatrudnienie w poszczególnych strukturach administracji publicznej może następować na różnych zasadach i odmienne mogą być też warunki pracy i wyzwania, jakie stoją przed pracownikami i urzędnikami. Należy mieć jednak na uwadze fakt, że wypalenie zawodowe jest problemem, którego nie można lekceważyć w żadnej ze sfer aktywności administracji publicznej. Wypalenie zawodowe może dotyczyć każdego z obszarów aktywności zawodowej człowieka i dlatego też muszą się liczyć z tym problemem wszystkie osoby zatrudnione w strukturach administracji. Jednakże ryzyko jego wystąpienia jest nieco inne w przypadku wykonywania poszczególnych rodzajów działalności i inne też będą uwarunkowania jego powstania w poszczególnych sferach działania administracji.

Istotną kwestią jest uwrażliwienie kadr zarządzających poszczególnymi instytucjami funkcjonującymi w ramach administracji publicznej na możliwość występowania jego objawów oraz stworzenie dogodnych warunków do podejmowania odpowiednich kroków zaradczych w przypadkach wypalenia u podległych pracowników. Istnieją pewne ogólne symptomy wystąpienia tego syndromu pozwalające na jego identyfikację. Wypalenie zawodowe definiowane jest kompleksowo jako uporczywy, negatywny stan związany z pracą, występujący u osób ogólnie

5 A. Błaś, Zarządzanie publiczne, [w:] Administracja publiczna, red. J. Boć, Wrocław 2013, s. 126. 
zdrowych. Charakteryzuje się on przede wszystkim wyczerpaniem, któremu towarzyszy dyskomfort psychiczny i fizyczny, poczucie zmniejszonej skuteczności, obniżona motywacja oraz dysfunkcyjne postawy i zachowania w pracy. Ten stan rozwija się stopniowo i wynika $\mathrm{z}$ rozbieżności między intencjami a realiami zawodu. Wypalenie często jest procesem samonapędzającym się z powodu nieadekwatnych strategii radzenia sobie w tym problemem ${ }^{6}$. Christina Maslach w swojej definicji eksponuje charakterystyczne elementy tego syndromu, którymi są: wyczerpanie emocjonalne (emotional exhaustion), depersonalizacja (depersonalization) i obniżona ocena dokonań osobistych (reduced personal accomplishment). Zgodnie z definicją przyjętą przez autorkę wypalenie zawodowe to psychologiczny zespół wyczerpania emocjonalnego, depersonalizacji oraz obniżonego poczucia dokonań osobistych, który może wystąpić u osób, które pracują z innymi ludźmi w pewien określony sposób ${ }^{7}$. Wypalenie zawodowe doświadczane jest jako stan wyczerpania fizycznego, umysłowego i emocjonalnego, a towarzyszą mu rozmaite objawy obejmujące fizyczne wycieńczenie, poczucie bezradności i beznadziejności. Charakterystyczna jest utrata złudzeń, negatywne wyobrażenie o sobie oraz negatywne postawy wobec pracy, ludzi i życia ${ }^{8}$.

Na podstawie metaanalizy wyników badań nad wypaleniem zawodowym R.K. James i B.E. Gilliland wyodrębnili szereg istotnych aspektów tego zjawiska. Dotyczą też one w znacznym stopniu wypalenia zawodowego, jakie może stać się udziałem osób zatrudnionych w administracji publicznej. Warto zwrócić uwagę na następujące kwestie, o których pisali autorzy: wypalenie i będący jego skutkiem kryzys mogą wystąpić u danej osoby kilka razy; wypalenie jest „zaraźliwe” i wywołuje dodatkowy stres innych pracowników; wypalenie nie jest chorobą i nie powinno się go rozpatrywać w kategoriach medycznych; nie należy go mylić z wymigiwaniem się od podejmowania obowiązków zawodowych ${ }^{9}$.

Uważa się, że szczególnie podatne na wypalenie są osoby mające w swojej pracy bezpośredni intensywny kontakt z innymi ludźmi zwłaszcza w sytuacji, w której niosą im pomoc. Dlatego też wypalenie jest szczególnie często spotykane wśród osób zatrudnionych w strukturach pomocy społecznej i osób zajmujących się szeroko pojmowaną interwencją kryzysową, np. u policjantów. Występuje ponadto szczególnie intensywnie tam, gdzie praca polega na dokonywaniu świad-

${ }^{6}$ W. Schaufeli, D. Enzmann, The burnout companion to studying practice a critical analysis, London 1998, cyt. za: M. Anczewska, P. Witaj, J. Roszczyńska, Wypalenie zawodowe, „Postępy Psychiatrii i Neurologii" 2005, nr 14 (2), s. 67-77.

${ }^{7}$ Ch. Maslach, Wypalenie w perspektywie wielowymiarowej, [w:] Wypalenie zawodowe przyczyny, mechanizmy, zapobieganie, red. H. Sęk, Warszawa 2000, s. 13-31.

8 A.M. Pines, E. Aronson, Career burnout: Causes and cures, New York 1988, s. 9-10, cyt. za: R.K. James, B.E. Gilliland, Strategie interwencji kryzysowej, Warszawa 2008, s. 472.

9 R.K. James, B. E. Gilliland, op. cit., s. 474, 475. 
czeń w bezpośrednich interakcjach z ich beneficjentami, np. w zawodach medycznych - u pielęgniarek, położnych i lekarzy oraz u nauczycieli ${ }^{10}$.

Czynniki powodujące wypalenie zawodowe klasyfikowane są w literaturze w trzech podstawowych grupach. Są to czynniki organizacyjne, do których w przypadku administracji publicznej należy zaliczyć zarówno model ustrojowy, jak i sposób organizacji pracy w urzędzie, ale także styl kierowania i stosunki jakie panują w danej jednostce. Ponadto wyróżnia się czynniki środowiskowe, do których w przypadku zagrożenia syndromem wypalenia zawodowego pracowników i urzędników administracji zaliczyć należy zarówno otoczenie prawne i ekonomiczne, jak i środowisko społeczne, w którym funkcjonuje dana jednostka administracji. Ponadto wyróżnia się indywidualne czynniki podmiotowe, wśród których istotne znaczenie odgrywają osobiste cechy, postawy i predyspozycje danej osoby. W przypadku tych uwarunkowań czynnikami ryzyka są przede wszystkim wysoki poziom empatii i wysoki poziom motywacji do wykonywanej pracy ${ }^{11}$. Zatrudnione w administracji osoby pracują ,z ludźmi i przepisami”, ich działalność w sferze wykonawczej ściśle regulowana jest przepisami prawa a z drugiej strony ich działalność dotyczy istotnych ludzkich spraw i podejmowana jest w konkretnym środowisku społecznym. Ta sytuacja ma decydujący wpływ na powstanie specyficznych uwarunkowań strukturalnych wypalenia zawodowego, jakiego mogą doświadczyć urzędnicy i inne osoby funkcjonujące w sferze wykonawczej państwa. Poniżej zostaną omówione czynniki organizacyjne i strukturalne, a następnie środowiskowe warunkujące powstanie lub zapobiegające powstaniu syndromu wypalenia zawodowego w tej grupie zawodowej.

\section{Czynniki organizacyjne i strukturalne warunkujące wypalenie zawodowe}

Wyniki badań prowadzonych nad wypaleniem zawodowym przeczą obiegowym opiniom na temat tego syndromu, a szczególnie tej, że wypalenie to problem osoby doświadczającej tego stanu. Christina Maslach i Michael P. Leiter konkludują swoje badania stwierdzeniem, że wypalenie nie jest problemem samego człowieka, ale otoczenia społecznego, w którym przyszło mu pracować. Struktura i funkcjonowanie miejsca pracy kształtują sposób, w jaki ludzie ze sobą współdziałają i jak wykonują swoją pracę. Istotne jest więc spostrzeżenie autorów, że

10 Por. E. Lisowska, Rozpoznawanie i przewidywanie wypalenia zawodowego nauczycieli, Kielce 2012.

11 Por. Ch. Maslach, M.P. Leiter, Wypalenie...; w licznych prezentowanych tam przykładach osób zaangażowanych w pracę, której warunki nie odpowiadały założeniom, które przyciągnęły pracowników do konkretnych organizacji i ich początkowe zaangażowanie w pracę trafiło w swoistą pustkę. 
kiedy miejsce pracy nie dostrzega człowieka, wzrasta ryzyko wypalenia, niosąc z sobą wysoką cenę, jaką przyjdzie zapłacić ${ }^{12}$. Wypalenie doświadczane jest przez jednostkę, ale organizacja, w której zawodowo funkcjonuje doświadczający tego stanu człowiek, nie może pozostać obojętna, gdyż to ona poniesie negatywne skutki wypalenia. Ponadto to właśnie czynniki związane z otoczeniem towarzyszącym pracownikowi w wykonywaniu jego obowiązków zawodowych przyczyniły się do jego powstania.

Jeżeli chodzi o czynniki organizacyjne leżące u źródeł wypalenia zawodowego istotne wnioski płyną z badań przeprowadzonych przez V. Savickiego i E.J. Cooleya. Jak zauważają autorzy, pracownicy, u których wypalenie przybrało największe rozmiary, mieli poczucie nikłego wpływu na procedury i politykę instytucji, brakowało im autonomii w obrębie wytycznych regulujących ich pracę, nie mieli jasności co do celów placówki, przez długi czas byli obciążani dużą ilością zadań. Możliwość podejmowania przez nich decyzji co do sposobu postępowania z klientami podlegała daleko idącym ograniczeniom i ogólnie pracownicy ci czuli się niedoceniani przez współpracowników i przełożonych ${ }^{13}$. Ustalenia poczynione podczas tych badań pozwalają więc zidentyfikować jako szczególnie narażone na wystąpienie syndromu wypalenia zawodowego osoby zatrudnione w strukturach scentralizowanych, szczególnie w okresach gwałtownych przemian warunkowanych m.in. czynnikami politycznymi, gdy pozamerytoryczne czynniki polityczne wpływają często rewolucyjnie na zakres obowiązków zawodowych i na stan osobowy w danej placówce. Wyniki badań uzyskanych w Polsce przez K. Jabłkowską i A. Borkowską potwierdzają opisane wyżej zależności. Autorkom udało się zidentyfikować następujące czynniki, które predysponują do powstania zespołu wypalenia zawodowego: poczucie obciążenia psychicznego pracą, brak pozytywnych wzmocnień w pracy w postaci różnych nagród, niepewność pracy związana m.in. z jej organizacją, gorsze kontakty społeczne przekładające się na brak wsparcia ze strony innych oraz niższe wykształcenie pracowników, mogące wiązać się z niższą samooceną danej osoby ${ }^{14}$. Ponadto autorki wykazały, że dla kobiet brak pozytywnych wzmocnień w postaci nagród w pracy oraz poczucie niepewności wywołane organizacją pracy są czynnikami bardziej obciążającymi niż dla mężczyzn. Z kolei mężczyźni jako taki czynnik postrzegają tylko poczucie zagrożenia ${ }^{15}$. Za to generalnie osoby z wysoką oceną własnych dokonań w mniejszym stopniu odczuwały stres w pracy, przy czym były mniej zależne od nagród

12 Ch. Maslach, M.P. Leiter, Prawda o wypaleniu zawodowym. Co robić ze stresem w organizacji, Warszawa 2011, s. 35.

13 V. Savicki, E.J. Cooley, The relationship of work environment and client contact to burnout in mental health professionals, ,Journal of Counseling and Development”1987, nr 65, s. 249-252, cyt. za: R.K. James, B.E. Gilliland, op. cit., s. 479.

14 K. Jabłkowska, A. Borkowska, Ocena nasilenia stresu w pracy a cechy zespołu wypalenia zawodowego u menedżerów, „Medycyna Pracy” 2005, nr 56 (6), s. 444.

15 Ibidem, s. 443. 
w pracy, cechowała je także mała podatność na wszelkie niepewności związane z organizacją pracy ${ }^{16}$. Stres jest jednym z czynników towarzyszących pracy, który w wysokim nasileniu w warunkach długotrwałego nieprzerwanego oddziaływania na pracowników wpływa na powstanie wypalenia zawodowego. Wyniki badań na ten temat zebrała B. Mańkowska, która potwierdziła tę tendencję także przeprowadzonymi przez siebie badaniami ${ }^{17}$.

Istotnym czynnikiem organizacyjnym korelującym z ryzykiem wystąpienia syndromu wypalenia zawodowego jest kwestia kontroli nad własną pracą. Jak zauważają Ch. Maslach i M.P. Leiter, ludzie chcą mieć możliwość dokonywania wyborów i podejmowania decyzji, wykorzystywania umiejętności myślenia i rozwiązywania problemów oraz wkładu w proces osiągania wyników, za które będą rozliczani. Istnieje ogromna różnica między byciem odpowiedzialnym a byciem ograniczanym przez sztywną politykę i rygorystyczny monitoring. Zdaniem autorów mechaniczne zarządzanie prowadzi do mechanicznego działania, a ścisłe monitorowanie obniża zdolność pracowników do przystosowania się i podjęcia inicjatywy ${ }^{18}$. Ponadto zdaniem tych autorów umiejętność określania priorytetów w codziennej pracy, dokonywanie wyborów co do właściwych metod działania i podejmowanie decyzji dotyczących zasobów są kluczowymi elementami składającymi się na profesjonalizm ${ }^{19}$. Dyrektywny styl kierowania organizacją jest więc jednym z czynników znacznie zwiększającym ryzyko wypalenia wśród pracowników.

W przypadku analizy struktur administracji publicznej pod kątem ryzyka wypalenia zawodowego i projektowania takich struktur, które będą to ryzyko minimalizować, istotną kwestią jest ustalenie optymalnego poziomu formalizacji organizacji; takiego, który zapewni odpowiedni poziom autonomii pracownikom w ramach wyznaczonych im prawem kompetencji. Jak zauważa A. Pakuła, w przypadku przeformalizowania organizacji, czyli w sytuacji przekroczenia optymalnego dla danej organizacji stopnia sformalizowania (zbyt duża liczba przepisów, zbyt duży stopień ich szczegółowości i rygorystyczności), następuje nadmierne usztywnienie, ujednolicenie działań i stosunków organizacyjnych, obniżenie zdolności kreacyjnych, zwiększona podatność na stosowanie przepisów w oderwaniu od celów i treści zadań ${ }^{20}$. Zakres formalizacji w przypadku administracji jest rzeczywiście szeroki, co nie oznacza, że musi być on w poszczególnych swoich dziedzinach drobiazgowy. Tam gdzie jest to możliwe i uzasadnione należałoby zalecić zastosowanie pewnego zakresu dyskrecjonalności regulacji kształtującej

16 Ibidem, s. 444.

17 B. Mańkowska, Wypalenie zawodowe. Źródła, mechanizmy, zapobieganie, Gdańsk 2016.

18 Ch. Maslach, M.P. Leiter, Prawda..., s. 26.

19 Ibidem, s. 64.

20 A. Pakuła, Jakość organizacji formalnej administracji publicznej a zagrożenie patologia (w świetle wybranych przykładów z obszaru administracji rządowej szczebla centralnego), [w:] Patologie w administracji publicznej, red. J.P. Suwaj, D.R. Kijowski Warszawa 2009, s. 606. 
sytuację prawną pracownika administracji publicznej, a w określonych obszarach rozszerzyć także zakres dyskrecjonalności działania w ramach wykonywania obowiązków służbowych. Andrzej Pakuła identyfikuje organizację formalną administracji jako wszystkie przepisy odnoszące się do jej celów; zadań; ustroju; zasad funkcjonowania; struktur organizacyjnych; form i sposobów realizacji zadań; spraw osobowych; pozycji i ról organizacyjnych członków tej organizacji; relacji z otoczeniem, bez względu na ich konkretną treść (przedmiot regulacji), źródło pochodzenia czy charakter. Autor zauważa, że proces stanowienia tych przepisów zarówno zewnętrznych, jak i wewnętrznych — w pełni odpowiada procesowi formalizacji ze wszystkimi konsekwencjami w tym niebezpieczeństwem błędów tego procesu ${ }^{21}$. Oczywiście zgodnie z polskimi założeniami ustrojowymi mieszczącymi się w standardzie kategorii demokratycznego państwa prawnego, administracja działa w granicach i na podstawie prawa. Jej stosunki z adresatami działań podejmowanych $\mathrm{w}$ procesie wykonywania prawa muszą być regulowane prawem powszechnie obowiązującym, gdyż to zapewnia obywatelowi pewność jego sytuacji prawnej i jest zgodne $\mathrm{z}$ interesem publicznym. Niemniej istotną kwestią jest prawne zagwarantowanie odpowiedniej elastyczności działania pozwalającej na adekwatne stosowanie przepisów w określonej sytuacji społecznej. Dlatego też na przykład pozytywnie należy ocenić obecne brzmienie art. 13 Ustawy z dnia 14 czerwca 1960 roku Kodeks postępowania administracyjnego (tekst jedn. Dz.U. z 2018 r. poz. 2096 ze zm.) stwarzającego dogodne warunki prawne dla stosowania koncyliacyjnych metod działania w rozstrzyganiu w sprawach, w których uwidaczniają się przeciwstawne interesy stron oraz przepisów art. 96 a i nast. tego kodeksu regulujących zastosowanie mediacji w postępowaniu administracyjnym. Takie podejście nie jest możliwe oczywiście we wszystkich przypadkach — zwłaszcza przy zastosowaniu konstrukcji decyzji związanej, niemniej rezygnacja ze ścisłej formalizacji postępowania i włączenie w proces decyzyjny, tam gdzie jest to możliwe, adresatów władczych rozstrzygnięć jest jednym z czynników budujących poczucie odpowiedzialności społecznej pracowników administracji publicznej i jednocześnie zdejmuje z nich częściowo poczucie osobistej odpowiedzialności, czy też raczej rozliczalności, a to z kolei przekłada się na uwarunkowania przeciwdziałające wypaleniu zawodowemu tej grupy pracowniczej.

Istotną kwestią korelującą z ryzykiem wystąpienia syndromu wypalenia zawodowego jest stan swoistego wymiaru wspólnotowości w zespołach pracowniczych czy po prostu w miejscu pracy. Autorzy generalnie są zgodni co do tego, że rzeczywista wspólnota w obrębie więzi profesjonalnych, której wytworzenie się wymaga oczywiście czasu i mozolnie budowanego zaufania jest czynnikiem przeciwdziałającym wypaleniu, a jej rozpad przyczynia się do powstania wypalenia wśród pracowników i generuje także inne niekorzystne zjawiska. Zwracają na to uwagę m.in. Ch. Maslach i M.P. Leiter, których zdaniem załamywanie się wspólno-

21 Ibidem, s. 607. 
ty uwidacznia się częstymi konfliktami, mniejszym wzajemnym wsparciem i szacunkiem oraz wzrostem poczucia wyobcowania pracowników ${ }^{22}$, co z kolei także jest czynnikiem ryzyka wystąpienia wypalenia zawodowego. Autorzy mają rację, twierdząc, że życie w organizacji sprowadza się do kontaktów międzyludzkich. Ich zdaniem np. kiedy nie ma pewności zatrudnienia, więzi tworzące społeczność są rozrywane. Wraz ze zmniejszeniem organizacyjnych zobowiązań wobec pracowników mają oni coraz mniej powodów by angażować się we wzajemne relacje ${ }^{23}$. Ta konstatacja dotyka tak istotnej kwestii, jak modele zatrudnienia w administracji publicznej. W związku z tymi poglądami system łupów, gdzie zatrudnienie zależy od trudnych do przewidzenia decyzji politycznych, i wszelkie sytuacje, w których brakuje stabilizacji stosunku pracy, są czynnikiem ryzyka jeżeli chodzi o syndrom wypalenia zawodowego w administracji publicznej.

Analiza zjawiska prowadzi więc do wniosków, że organizacja struktur i sposobu pracy ma decydujący wpływa na to, czy syndrom wypalenia zawodowego w określonej jednostce administracji publicznej wystąpi, czy nie. Można więc uznać, że elastyczne formy pracy i dopuszczalna prawem autonomia pracownika w określaniu sposobu wykonywania zadań, co przede wszystkim dotyczy rozliczania wyników pracy, a nie drobiazgowego mikrozarządzania samym procesem wykonywania obowiązków, a także sprawiedliwość oceny budują taki klimat pracy, który zapobiega wypaleniu zawodowemu. Ponadto ogromne znaczenie w tym przypadku mają jasne cele działania organu, o co niestety trudno w przypadku gwałtownych zmian przepisów warunkowanych racjami politycznymi.

\section{Czynniki środowiskowe warunkujące wypalenie zawodowe}

Wykonywanie zadań publicznych przez administrację to, parafrazując definicję profesora Jana Bocia, zaspokajanie zbiorowych potrzeb obywateli i ich potrzeb indywidualnych wynikających ze współdziałania tych osób ze społecznością ${ }^{24}$. Następuje więc ono zawsze w określonym środowisku i na rzecz określonej wspólnoty i jednostek. Środowisko to oddziałuje zaś w sposób długofalowy i doraźny na warunki pracy zatrudnionych w administracji osób.

Czynnikami środowiskowymi wpływającymi na warunki pracy osób zatrudnionych w administracji publicznej są wszelkie istotne elementy otoczenia administracji, w rozumieniu jakie terminowi „otoczenie” nadaje się na gruncie nauki organizacji i zarządzania. Chodzi tu więc zarówno o otoczenie prawne, otoczenie

22 Ch. Maslach, M.P. Leiter, Prawda..., s. 72-73.

23 Ibidem, s. 73.

24 J. Boć, Pojęcie administracji..., s. 15. 
ekonomiczne, jak i otoczenie w wymiarze podmiotowym, czyli adresatów rozstrzygnięć wydawanych przez organy administracji i świadczeniobiorców określonych świadczeń materialnych i niematerialnych, jakich dokonuje się w ramach działalności placówek zaliczanych do struktur administracji. W wymiarze podmiotowym wyróżnić też należy wszelkie inne podmioty, które wchodzą w relacje z pracownikami administracji.

Jeżeli chodzi o uwarunkowania środowiskowe, analiza istoty zjawiska przez pryzmat kontaktów, w jakie wchodzą w swojej praktyce zawodowej osoby zatrudnione w strukturach administracji, pozwala na wyodrębnienie szeregu czynników, które mogą mieć istotny wpływ na ryzyko wystąpienia wypalenia zawodowego. Do najistotniejszych należy kwestia stabilności prawa i składu osobowego, a czasem wręcz istnienia instytucji publicznych, z którymi współpracuje pracownik zatrudniony w określonej strukturze organizacyjnej administracji. Brak stabilizacji jest jednym z czynników ryzyka wystąpienia syndromu wypalenia zawodowego. Innym istotnym czynnikiem, jest ,profil” adresatów działań wykonywanych przez pracownika. Poniżej zostaną omówione uwarunkowania zachodzące w przypadku struktur pomocy społecznej. Praktyka relacji z adresatami działań ma kluczowe znaczenie dla tego, czy dana praca będzie stanowiła obciążenie emocjonalne mogące skutkować wypaleniem, czy też nie. Jeszcze jednym z istotnych czynników mających związek z ryzykiem wystąpienia wypalenia jest system edukacji, w ramach którego przygotowywane do wykonywania obowiązków zawodowych są przyszłe kadry administracji publicznej. System ten, w świetle przytoczonych w tym opracowaniu badań, powinien poza odpowiednim przygotowaniem merytorycznym dawać także wysoki status formalny ${ }^{25}$ — gdyż te dwa czynniki są swoistymi: „szczepionkami przeciwko wypaleniu zawodowemu”.

Istotnym czynnikiem warunkującym wystąpienie wypalenia zawodowego u osób zatrudnionych w strukturach pomocy społecznej i w innych jednostkach, których pracownicy spotykają się z osobami w trudnym położeniu życiowym, są syndromy traumatyzacji pośredniej i wyczerpania współczuciem, które mają związek ze zjawiskiem przeciwprzeniesienia - polega ono na przypisywaniu osobie, której niesie się pomoc, cech i zachowań osób wiele znaczących dla niosącego pomoc lub własnych ${ }^{26}$. Traumatyzacja pośrednia i wyczerpanie współczuciem zostały uznane przez K.W. Saakvinte i L.A. Pearlmana za ryzyko zawodowe związane z wykonywaniem pracy polegającej na kontakcie z osobami doświadczającymi intensywnych i długotrwałych urazów, co trwale zmienia strukturę psychiczną pomagających im pracowników instytucji niosących pomoc ${ }^{27}$. Ma to bezpośredni związek z idealistycznym podejściem do pracy oraz z głęboką

25 Por. powołane niżej wyniki badań K. Jabłkowskiej i A. Borkowskiej, które zidentyfikowały wyższe wykształcenie jako jeden z czynników przeciwdziałających wypaleniu.

26 Por. R.K. James, B.E. Gilliland, op. cit., s. 478.

27 K.W. Saakvinte, L.A. Pearlman, Transforming the pain: A workbook on vicarious traumatization, New York 1996, cyt. za: R.K. James, B. E. Gilliland, op. cit., s. 479. 
empatią, którą często charakteryzują się pracownicy służb socjalnych. W miarę jak pracownik służb społecznych coraz większą wagę przykłada do uzyskiwania natychmiastowych efektów w niesieniu pomocy i pogłębianiu więzi z klientem, coraz trudniej przychodzi mu asertywne zachowanie wobec żądań klienta ${ }^{28}$. James i Gilliland zwracają uwagę na pewne charakterystyczne zachowania pracowników będące symptomami zbliżającej się traumatyzacji pośredniej i będącego jej skutkiem wypalenia zawodowego. Chodzi tu przede wszystkim o takie postawy, jak: branie przez pracownika socjalnego odpowiedzialności za osobę, której udziela się wsparcia, co przejawia się w takich zachowaniach jak przeciąganie sesji ponad zwykły limit, kontakty z klientem o różnych porach dnia i nocy, próby stosowania dramatycznych rozwiązań wobec niemożliwych do opanowania przypadków. Ponadto pracownik odczuwa autentyczne cierpienie z powodu niepowodzeń klienta, wpada we frustrację, co w efekcie powoduje albo swoiste zobojętnienie na realne potrzeby klienta albo prowadzi pracownika do zaniedbywania jego własnych potrzeb $^{29}$.

\section{Aby nie stąpać po zgliszczach}

Wypalenie zawodowe może dotyczyć pojedynczych osób funkcjonujących w określonej strukturze, ale z uwagi na charakter tego zjawiska istnieje ryzyko dotknięcia tym syndromem większości lub nawet wszystkich pracowników zatrudnionych w danej placówce. Osoby sprawujące funkcje kierownicze w administracji publicznej powinny więc podejmować odpowiednie kroki zaradcze. Zapobieganie wypaleniu zawodowemu polega na wprowadzeniu odpowiednich systemowych rozwiązań organizacyjnych oraz na rutynowym stosowaniu specjalnych procedur zapobiegających wypaleniu i znoszących pierwsze objawy tego syndromu wśród pracowników.

Jedną z takich procedur jest superwizja, którą można określić jako konsultacyjną formę reakcji na specyficzne trudności zawodowe charakterystyczne dla określonej placówki lub określonego typu działalności zawodowej. Nadaje się ona do zastosowania w każdym środowisku pracowniczym i powinna być instrumentem przeciwdziałania wypaleniu zawodowemu we wszelkich sferach działania administracji publicznej, w których emocjonalne obciążenia związane z wykonywanymi obowiązkami służbowymi, w tym stres, przeciążenie pracą i inne jej uwarunkowania, stanowią zagrożenie dla dobrostanu pracownika. Superwizje mogą być indywidualne lub grupowe. Mogą mieć postać superwizji koleżeńskich i superwizji trenerskich. Zdaniem B. Mańkowskiej superwizja traktowana jako

28 R.K. James, B. E. Gilliland, op. cit., s. 479.

29 Ibidem, na podstawie S. Van Auken, Youth counselor burnout, „Personnel and Guidance Journal" 1979, nr 58, s. 143-144. 
regularny konsultacyjny proces ma na celu ochronę zdrowia psychicznego pracowników, ich dobrostanu, zachowania wrażliwości i indywidualnego wymiaru kontaktu z osobą potrzebującą pomocy. Ponadto jej celem jest dobro instytucji, która ma zapewnić optymalny poziom realizacji misji i wytyczonych jej celów ${ }^{30}$.

W Polsce superwizja została przewidziana ustawowo jako sposób wsparcia i profesjonalizacji pracowników socjalnych. Zgodnie z regulacją art. 121a ust. 1 Ustawy z dnia 12 marca 2004 roku o pomocy społecznej (tekst jedn. Dz.U. z 2018 r. poz. 1508 ze zm.) superwizja pracy socjalnej polega na ustawicznym rozwoju zawodowym pracowników socjalnych służącemu utrzymaniu wysokiego poziomu świadczonych usług, zachowaniu i wzmacnianiu kompetencji zawodowych, udzielaniu wsparcia, poszukiwaniu źródeł trudności w pracy i możliwości ich pokonywania. Ustęp drugi tej regulacji gwarantuje każdemu pracownikowi socjalnemu prawo do korzystania z prowadzonej przez superwizorów superwizji pracy socjalnej. Przepisy tej ustawy oraz Rozporządzenia Ministra Rodziny, Pracy i Polityki Społecznej z dnia 2 grudnia 2016 roku w sprawie superwizji pracy socjalnej (Dz.U. z 2016 r. poz. 2087) przewidują przesłanki wykonywania funkcji superwizora oraz standardy, jakim powinny odpowiadać szkolenia dla nich i warunki ich przeprowadzania. Ponadto rozporządzenie reguluje m.in. cele, wytyczne i standard superwizji pracy socjalnej. Zgodnie z $\S 2$ ust. 1 powołanego tu rozporządzenia celem superwizji jest wprowadzanie i utrzymywanie profesjonalnych standardów praktykowania pracy socjalnej; wzmacnianie kompetencji zawodowych pracowników socjalnych; udzielanie wsparcia pracownikom socjalnym, sprzyjanie ich rozwojowi zawodowemu oraz zapobieganie wypaleniu zawodowemu; zdobywanie umiejętności pozwalających na prawidłowe identyfikowanie trudności w pracy, ich źródeł oraz sposobów rozwiązywania; wzmacnianie umiejętności komunikowania się pracowników socjalnych z osobami korzystającymi z pomocy społecznej, współpracownikami i instytucjami oraz otoczeniem, w którym wykonują pracę; podnoszenie skuteczności pracy pracowników socjalnych; nawiązanie relacji superwizyjnej pomiędzy pracownikiem socjalnym a superwizorem. Model superwizji, który znalazł zastosowanie w polskich rozwiązaniach pomocy socjalnej, to model tzw. superwizji trenerskiej — superwizję prowadzi odpowiednio przeszkolony certyfikowany superwizor. Pracownik socjalny zgodnie $\S 3$ analizowanego tu rozporządzenia ma prawo wnioskować o superwizora i formę superwizji, która jak stanowi ust. 2 tej regulacji — może być realizowana w formie indywidualnej lub grupowej. Przepisy wprowadzają wysoki standard poufności superwizji, przewidują także rozwiązania gwarantujące bezstronność superwizora.

W Polsce prowadzone były specjalne programy pilotażowe, które potwierdziły wysoką skuteczność superwizji jako instrumentu przeciwdziałającemu wypaleniu zawodowemu wśród pracowników socjalnych, ale także wśród innych grup zawodowych. Obligatoryjne superwizje były np. jednym z elementów pro-

30 B. Mańkowska, Wypalenie..., s. 244. 
jektu pilotażowego Sukces gdańskiej rodziny, który analizowała B. Mańkowska. Superwizje według założeń tego projektu były obligatoryjnym stałym procesem konsultacyjnym wyznaczającym nowe standardy realizacji zadań pracownika socjalnego. Ponadto w projekcie tym oddzielono postępowanie administracyjne od pracy socjalnej i zastosowano nowe narzędzia takiej pracy. Zdaniem autorki, która uczestniczyła w tym projekcie jako superwizorka i ewaluatorka jego wyników, superwizjami powinni zostać objęci nie tylko sami pracownicy socjalni, ale także osoby przyznające świadczenia i konsultanci: psychologowie oraz osoby prowadzące konsultacje prawne, jak również specjaliści z zakresu poradnictwa rodzinnego ${ }^{31}$.

W literaturze opisane są przypadki stosowania rozwiązań, które generalnie minimalizować będą ryzyko wystąpienia syndromu wypalenia zawodowego. Taki system, funkcjonujący w instytucji niosącej pomoc poszkodowanym dzieciom, został opisany przez R.K. Jamesa i B.E. Gillilanda ${ }^{32}$, poniżej scharakteryzuję jego kluczowe elementy.

Po pierwsze, zapewnia się odpowiednie materialne zaplecze funkcjonowania pracowników, które pozwala na autonomię w wykonywaniu obowiązków. Pracownicy mogą skoncentrować się na wykonywaniu zadań, a nie muszą sami zabiegać o przedmioty czy miejsce potrzebne do wykonywania obowiązków służbowych oraz nie muszą sami wykonywać administracyjnych czynności obsługi nazywanych potocznie papierkową robotą. Istotną kwestią jest design miejsc i przedmiotów używanych w pracy i wystarczająca ilość powierzchni, na której się pracuje, i rzeczy w pracy potrzebnych. Jak piszą autorzy: każdy z terapeutów ma swój gabinet, komputery, telefon komórkowy, kamerę cyfrową i inny potrzebny sprzęt. Zapewniona jest wystarczająca liczba materiałów i potrzebnych urządzeń. Miejsca, w których się pracuje, są czyste i dobrze oświetlone, a wystrój wnętrz radosny. Pracownicy dysponują biblioteką i mają do dyspozycji filmy i przedmioty służące zarówno własnemu rozwojowi zawodowemu, jak i pracy z dziećmi.

Po drugie realnie planuje się czas pracy i obciążenie pracowników i zapewnia nienaruszalność czasu prywatnego. Dyrekcja respektuje prawo pracownika do spędzania czasu z rodziną i propaguje takie postawy. Gdy w sytuacjach krytycznych pracownik przekracza czterdziestogodzinowy tygodniowy wymiar czasu pracy, natychmiast po opanowaniu sytuacji dostaje wolny czas do swojej dyspozycji. Nikt nie pracuje podczas przerw na obiad. Dyrekcja ośrodka stale współpracuje z podmiotem nadzorującym jego pracę, by zapewnić środki na jego funkcjonowanie niezbędne do zwiększenia zatrudnienia warunkowanego wzrostem ilości zadań ośrodka. Ponadto zapewnia się pracownikom ciągły system wsparcia, którego elementem jest superwizja oraz dostępne są możliwości odreagowania trauma-

31 B. Mańkowska, Wypalenie..., s. 243; por. też. B. Mańkowska, Postulaty uczestników zmierzające do usprawnienia funkcjonowania opieki społecznej w Polsce, [w:] Doskonalenie zawodowe - superwizja, red. T. Popiołek et al., Sopot 2007, s. 51-68.

32 R.K. James, B.E. Gilliland, op. cit., s. 483-484. 
tycznych doświadczeń związanych z pracą. Placówka dba o wytworzenie sieci współpracy i wsparcia, m.in. pracownicy pracują metodą zespołową, a terapeuci otrzymują w stałym trybie pozytywne wzmocnienia od przełożonych i innych współpracowników.

Kluczową sprawą jest dobór personelu. W procesie rekrutacji bada się rzeczywiste predyspozycje kandydatów do wykonywania tego typu pracy i takie postępowanie stosuje się także wewnątrz instytucji przy dobieraniu osób zajmujących się określonymi typami przypadków. Jest to bardzo ważne, gdyż, jak zauważają Ch. Maslach i M.P. Leiter, wypalenie jest zawsze bardziej prawdopodobne, kiedy między charakterem pracy a charakterem osoby ją wykonującej występuje duży brak dopasowania ${ }^{33}$. Istotnym czynnikiem może być też sposób przygotowania personelu angażujący długi czas przygotowania do wykonywania zawodu. W badaniach udowodniono, że osoby z długim stażem zawodowym nie wykazują tendencji do wypalenia, natomiast zaobserwowano ten syndrom u osób z krótkim stażem zawodowym: po półtorarocznej pracy u pielęgniarek psychiatrycznych i np. już po dwuletniej pracy u adwokatów ${ }^{34}$.

Misja, którą niosą struktury powołane do wykonywania zadań publicznych, może być czynnikiem wspierającym działania przeciwdziałające syndromowi wypalenia zawodowego organów administracji publicznej, ale w pewnych warunkach może być też czynnikiem je wzmacniającym. Zdaniem A.M. Pines analizującej problem z punktu widzenia ludzkiej motywacji do czynienia w życiu rzeczy pożytecznych i ważnych w sytuacji, gdy ludzie próbują znaleźć sens swojego życia w pracy, a mają poczucie, że zawiedli, wynikiem jest wypalenie ${ }^{35}$. Wydaje się, że będzie tak również w sytuacji, w której pracownicy będą dawali z siebie bardzo wiele, ale ich wysiłki będą niweczone przez uwarunkowania systemowe panujące w danej strukturze administracji publicznej lub w skali państwa. Jak zauważają Ch. Maslach i M.P. Leiter głównym powodem, dla którego ludzie wiążą się z organizacjami, jest robienie czegoś, co ma znaczenie. Synergia pojawiająca się między osobistymi wartościami człowieka a wartościami organizacji, które przyciągnęły go do podjęcia pracy właśnie tam, może być potężną siłą napędową wyzwalającą twórczą energię. Siła ta zachęca ludzi do ponadprzeciętnego wkładu i pozwala współpracować ludziom o różnych uwarunkowaniach ekonomicznych, politycz-

33 Ch. Maslach, M.P. Leiter, Prawda..., s. 26.

34 S. Tucholska, Wypalenie zawodowe u nauczycieli. Psychologiczna analiza zjawiska i jego osobowościowych uwarunkowań, Lublin 2009, cyt. za: B. Mańkowska, Wypalenie..., s. 178. Tę tendencję potwierdzają także inne badania np. przeprowadzone wśród pracowników pomocy społecznej przez B. Mańkowską, zob. B. Mańkowska, Poziom wypalenia zawodowego wśród pracowników socjalnych miejskich ośrodków pomocy społecznej, „Praca Socjalna” 2014, nr 1, s. 82-96; B. Mańkowska, W trosce o pracownika. Ryzyko wypalenia zawodowego pracownika pomocy spotecznej, „Przegląd Psychologiczny” 2015, nr 58 (1), s. 83-101.

35 A.M. Pines, Wypalenie w perspektywie egzystencjalnej, [w:] Wypalenie zawodowe. Przyczyny i zapobieganie, red. H. Sęk, Warszawa 2012, s. 32. 
nych i kulturowych ${ }^{36}$. Misją organów administracji publicznej jest realizowanie zadań publicznych, o czym pisał m.in. A. Błaś, wskazując, że działania państwa i samorządu terytorialnego w realizacji tej misji sprowadzają się do ochrony obywateli i zaspakajania zbiorowych potrzeb, które przekraczają możliwości obywatela i zrzeszeń obywateli; chodzi tu o ochronę, potrzeby bytowe i kulturalne ${ }^{37}$. Zakładając, że kandydaci do zawodów urzędniczych i pracy w szeroko pojmowanych strukturach wykonujących zadania publiczne mieli świadomość takich właśnie celów działania administracji publicznej, istotne jest podtrzymywanie ich pozytywnej motywacji do pracy właśnie przez uwypuklanie znaczenia, jakie ich praca ma dla społeczeństwa i poszczególnych jednostek funkcjonujących w jego obrębie. Oczywiście sprawa nie jest prosta, gdyż na działanie osób pracujących w administracji nakłada się szereg czynników, chociażby takich, o jakich pisze R. Kusiak-Winter, analizując kwestie współistnienia i zależności zasady praworządności i zasady sprawności, które zdaniem autorki należy postrzegać jako wynik głębokiego przenikania się i wzajemnego determinowania uwarunkowań prawnych i ekonomicznych w administracji publicznej. Autorka dostrzega przy tym pewien dysonans odmiennych wartości, na straży których stoją z jednej strony wolny rynek umożliwiający generowanie policzalnych zysków, a z drugiej dobro wspólne i interes publiczny, przy którym trudno o wymierność i policzalność. Autorka aprobuje przy tym ujęcie, które nakazuje organom administracji opowiadanie się za wartościami natury fundamentalnej — chodzi tu o podstawowe wartości ludzkie $^{38}$. Niemniej pracownik administracji publicznej, niezależnie od motywacji jaką kieruje się w swojej pracy, staje przed realiami, które mogą go przerosnąć i z jednej strony możemy udzielać mu rad takich, jakich udzielał przed radiowymi występami autorowi Buszującego w zbożu Jerome'owi D. Salingerowi jego brat Seymour: „kiedy występujesz myśl o grubej paniusi”, co sprowadza się do założenia, że każde działanie administracji dotyka określonego człowieka i jego indywidualnych spraw, niemniej z drugiej strony należy też myśleć o człowieku, którym jest urzędnik. To zaś zadanie dla ustrojodawcy i osób mających wpływ na projektowanie formalnej struktury administracji, dla osób zarządzających placówkami wykonującymi zadania publiczne i wreszcie zadanie dla samych urzędników i pracowników administracji publicznej, a to ostatnie sprowadza się to tego, by osoby zatrudnione w strukturach administracji publicznej były dla siebie kolegami i współpracownikami — dosłownie.

36 Ch. Maslach, M.P. Leiter, Prawda..., s. 165.

37 A. Błaś, Z problematyki prywatyzacji zadań samorządu terytorialnego, „Przegląd Prawa i Administracji” 2000, nr 45, s. 34.

38 R. Kusiak-Winter, Wartości i antywartości w prawie administracyjnym z perspektywy nauki administracji, [w:] Antywartości w prawie administracyjnym, red. A. Błaś, Warszawa 2016, s. 50 . 


\section{Bibliografia}

Błaś A., Z problematyki prywatyzacji zadań samorzadu terytorialnego, „Przegląd Prawa i Administracji” 2000, nr 45.

Błaś A., Zarządzanie publiczne, [w:] Administracja publiczna, red. J. Boć, Wrocław 2013.

Boć J., Konteksty wyróżnienia administracji publicznej, [w:] Administracja publiczna, red. J. Boć, Wrocław 2013.

Boć J., Pojęcie administracji, [w:] Prawo administracyjne, red. J. Boć, Wrocław 2010.

Jabłkowska K., Borkowska A., Ocena nasilenia stresu w pracy a cechy zespotu wypalenia zawodowego u menedżerów, „Medycyna Pracy” 2005, nr 56 (6).

James R.K., Gilliland B.E., Strategie interwencji kryzysowej, Warszawa 2008.

Kusiak-Winter R., Wartości i antywartości w prawie administracyjnym z perspektywy nauki administracji, [w:] Antywartości w prawie administracyjnym, red. A. Błaś, Warszawa 2016.

Lisowska E., Rozpoznawanie i przewidywanie wypalenia zawodowego nauczycieli, Kielce 2012.

Mańkowska B., Postulaty uczestników zmierzające do usprawnienia funkcjonowania opieki społecznej w Polsce, [w:] Doskonalenie zawodowe — superwizja, red. T. Popiołek, E. Zubrzycka, R. Żebrowska-Kreft, B. Mańkowska, Sopot 2007.

Mańkowska B., Wypalenie zawodowe. Źródła, mechanizmy, zapobieganie, Gdańsk 2016.

Maslach Ch., Leiter M.P., Prawda o wypaleniu zawodowym. Co robić ze stresem w organizacji, Warszawa 2011

Maslach Ch., Wypalenie w perspektywie wielowymiarowej, [w:] Wypalenie zawodowe przyczyny, mechanizmy, zapobieganie, red. H. Sęk, Warszawa 2000.

Pakuła A., Jakość organizacji formalnej administracji publicznej a zagrożenie patologia (w świetle wybranych przykładów z obszaru administracji rzadowej szczebla centralnego), [w:] Patologie w administracji publicznej, red. J.P. Suwaj, D.R. Kijowski, Warszawa 2009.

Pines A.M., Wypalenie w perspektywie egzystencjalnej, [w:] Wypalenie zawodowe. Przyczyny izapobieganie, red. H. Sęk, Warszawa 2012.

Schaufeli W., Enzmann D., The burnout companion to studying practice, a critical analysis, London 1998.

Tucholska S., Wypalenie zawodowe u nauczycieli. Psychologiczna analiza zjawiska i jego osobowościowych uwarunkowań, Lublin 2009.

\section{Burnout syndrome in public administration}

\section{Summary}

Occupational burnout is a state experienced by an employee in the domain of their psyche, somatics and social interactions. This phenomenon has a huge impact on the functioning of the structure in which this person is employed. In the case of employment in public administration institutions, the occurrence of the burnout syndrome is conditioned by specific factors having to do with the organizational and workplace culture-related conditions within a given institution, as well as systemic and organizational foundations of the administrative structure itself. The burnout syndrome in public administration officials and employees occurs at a similar frequency as in the entire working population; however, for those employed in aid-providing institutions, the risk is notably higher. As 
for the remedies, a major role is played by supervision and appropriate organizational climate that provides support and respect for other-than-professional areas of social functioning of an employee or a public administration official.

Keywords: burnout, public administration, public officers, structures of public administration, employment relationships in public administration. 